University of Nebraska - Lincoln

DigitalCommons@University of Nebraska - Lincoln

Faculty Publications, Classics and Religious

Studies Department

7-1994

\title{
Three Fragments from Qumran Cave 4 and Their Relationship to the Temple Scroll
}

Sidnie White Crawford

University of Nebraska-Lincoln, scrawford1@unl.edu

Follow this and additional works at: https://digitalcommons.unl.edu/classicsfacpub

Part of the Classics Commons

Crawford, Sidnie White, "Three Fragments from Qumran Cave 4 and Their Relationship to the Temple Scroll" (1994). Faculty Publications, Classics and Religious Studies Department. 100.

https://digitalcommons.unl.edu/classicsfacpub/100

This Article is brought to you for free and open access by the Classics and Religious Studies at DigitalCommons@University of Nebraska - Lincoln. It has been accepted for inclusion in Faculty Publications, Classics and Religious Studies Department by an authorized administrator of DigitalCommons@University of Nebraska - Lincoln. 
"All rights reserved. Except for brief quotations used for purposes of scholarly citation, none of this work may be reproduced in any form by any means without written permission from the publisher. For information address the University of Pennsylvania Press, 3905 Spruce Street, Philadelphia, Pennsylvania 19104-4112." Used by permission.

The Jewish Quarterly Review, LXXXV, No. 1-2 (July-October, 1994) 259-273

\title{
THREE FRAGMENTS FROM QUMRAN CAVE 4 AND THEIR RELATIONSHIP TO THE TEMPLE SCROLL*
}

\author{
Sidnie White Crawford, Albright College
}

The three fragments presented in this article are part of the cache of manuscript fragments from Cave 4, discovered in 1952. John Strugnell, the original editor, placed these fragments with 4Q365, a manuscript which he named, along with 4Q364, 366, and 367, 4QPentateuchal Paraphrases (now called 4QReworked Pentateuch). ${ }^{1}$ The identification of these three fragments with $4 \mathrm{Q} 365$ is, however, problematic. Strugnell made his original identification on the basis of similarity between the handwriting of the fragments and 4Q365, and because the contents of the fragments is not incompatible with 4Q365. However, in his editio princeps of the Temple Scroll, Yigael Yadin ascribed all three fragments to the Temple Scroll $\left(11 \mathrm{QT}^{\mathrm{a}}\right)$ as a second copy of that composition, parallel to the one from cave $11 .^{2}$ Strugnell, on the other hand, has continued to assert that these fragments belong to $4 \mathrm{Q} 365$, one of the manuscripts of $4 \mathrm{QRP}{ }^{3}$ Tov and I, in the editio princeps of $4 \mathrm{Q} 365$, have followed a middle path; we have assigned one of the fragments (identified in Yadin as pl. 40,\#1) to 4Q365 for reasons I will outline below, and two of them (identified in Yadin as pl. 38, \#5 and pl. 40, \#2), along

\footnotetext{
* I would like to thank Emanuel Tov for his unstinting helpful criticism and advice on various aspects of this paper.

14 QPentateuchal Paraphrases was eventually assigned by Strugnell to Emanuel Tov and me for editing. See now Tov and White, "4QReworked Pentateuch," DJD 13 (Oxford, forthcoming).

${ }^{2}$ Yigael Yadin, The Temple Scroll (rev. Eng. ed.; Jerusalem, 1983), vol. 3, supplementary plates. For other discussions of these fragments, see H. A. Mink, "The Use of Scripture in the Temple Scroll and the Status of the Scroll as Law," Scandinavian Journal of the Old Testament 1 (1987): 20-50; E. Qimron, "Further New Readings in the Temple Scroll," IEJ 37 (1987): 31-35; H. Stegemann, "The Origins of the Temple Scroll," Supplements to Vetus Testamentum 40 (1986): 23556; M. Wise, A Critical Study of the Temple Scroll from Qumran Cave 11 (Chicago, 1990); B. Z. Wacholder, "The Fragmentary Remains of 11QTorah (Temple Scroll)," HUCA 62 (1991): 1-116.

${ }^{3}$ For a written reflection of his views, see B. Z. Wacholder, The Dawn of Qumran (Cincinnati, 1983), pp. 205-206.
} 
with three other fragments, to an appendix of $4 \mathrm{Q} 365$, which we have called 4Q365a. However, the identification of these fragments with either 4QReworked Pentateuch or 11QTemplea is still a matter of debate. I hope in this article to clarify the status of the fragments vis-a-vis both $4 \mathrm{QRP}$ and $11 \mathrm{QT}^{\mathrm{a}}$.

$4 Q R e w o r k e d$ Pentateuch contains a running text of the Pentateuch (from Genesis to Deuteronomy), interlaced with exegetical additions and omissions. ${ }^{4}$ One fragment presented in this paper, frag. 23, fits this description. However, two of these fragments, $2^{*}$ and $3^{*}$, which do not contain any biblical text (see below for transcription and translation), cannot for that reason belong to 4QRP. Therefore, Strugnell's original identification of frags. $2^{*}$ and $3 *$ with 4Q365 should be rejected. As mentioned, Yadin ascribed all three to the Temple Scroll, since material in these fragments often is reminiscent of, and in one case parallel to, material in $11 \mathrm{QT}^{\mathrm{a}}$. That is, col. i, lines $8-10$ of frag. $2 *$ (Yadin pl. 38, \#5), parallels $11 \mathrm{QT}^{\mathrm{a}}$ xxxviii $12-15$, and frag. $2^{*}$, col. ii parallels $11 \mathrm{QT}^{\mathrm{a}}$ xli 4 xlii 3 . In addition, frag. $3^{*}$ has contents which are reminiscent of the contents of $11 \mathrm{QT}^{\mathrm{a}}$ (i.e., building specifications for the temple). However, as will be seen below, there are problems with the identification of these fragments as part of $11 \mathrm{QT}^{\mathrm{a}}$. In the one case where frag. $2^{*}$ and $11 \mathrm{QT}^{\mathrm{a}}$ have parallel content, the remains of the two columns of frag. $2 *$ preclude incorporating all of the material from the parallel section of 11QT ${ }^{\mathrm{a}}$ into its columns (see below). As for the other fragment (Yadin pl. 40,\#2), it has no obvious location in $11 \mathrm{QT}^{\mathrm{a}}$. If these fragments do constitute another copy of the Temple Scroll, it must have been a copy differing from $11 \mathrm{QT}^{\mathrm{a}}$ and $11 \mathrm{QT}^{\mathrm{b}}$. In order to overcome this problem, Michael Wise identified these two fragments $\left(2^{*}\right.$ and $\left.3^{*}\right)$, along with frag. 23 of $4 \mathrm{Q} 365$ (Yadin pl. 40, \#1), not as the Temple Scroll, but as part of a source for the Temple Scroll. ${ }^{5}$ Hartmut Stegemann has also suggested that these fragments are part of a source for the Temple Scroll, but in his view all of these fragments are part of $4 \mathrm{Q} 365$, which, as part of the larger composition which we have named $4 \mathrm{QRP}$, is in itself a

\footnotetext{
${ }^{4}$ E. Tov, "The Textual Status of 4Q364-367 (4QPP)" in The Madrid Qumran Congress: Proceedings of the International Congress on the Dead Sea Scrolls, Madrid, 18-21 March, 1991, ed. J. Trebolle Barrera and L. Vegas Montaner (Madrid/ Leiden, 1992), pp. 43-82.

${ }^{5}$ Wise, A Critical Study, pp. 58-59.
} 
source for the Temple Scroll. ${ }^{6}$ Wacholder, on the other hand, designates frags. $2^{*}, 3^{*}$ and frag. 23 as 4 QparaTorah, but then reconstructs them as part of $11 \mathrm{QT}^{\mathrm{a}} .{ }^{7}$ However, I will argue that frag. 23 does belong to $4 \mathrm{Q} 365$, while frags. $2 *$ and $3 *$ may belong either to a different recension of the Temple Scroll than $11 \mathrm{QT}^{\mathrm{a}}$, or may be a part of a source for the Temple Scroll.

Frag. 23, which I believe belongs to $4 \mathrm{Q} 365$, is presented below (23 is the fragment's number in the enumeration of the fragments of $4 \mathrm{Q} 365){ }^{8}$

\section{top margin}

1

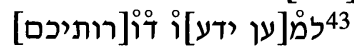

2

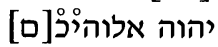

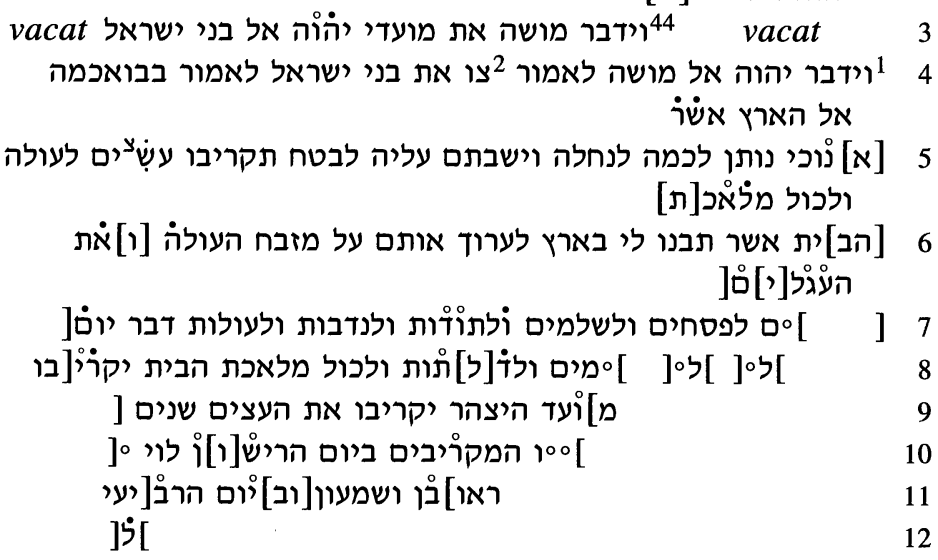

Translation of the additional material: (lines 4-11):

4 ... saying, when you come to the land which

5 I am giving to you for an inheritance, and you dwell upon it securely, you will bring wood for a burnt offering and for all the wo[r]k of

\footnotetext{
${ }^{6}$ Stegemann, "Origins of the Temple Scroll," pp. 237 and 253.

7 Wacholder, "The Fragmentary Remains."

${ }^{8}$ For photographs the reader is referred to Tov and White, "4QReworked Pentateuch," DJD 13, or Yadin, The Temple Scroll. For a complete discussion of all the characteristics of this and the other fragments, see DJD 13.
} 
6 [the h] ouse which you will build for me in the land, to arrange it upon the altar of burnt offering, and the calv[es

7 ]for passover sacrifices and for whole burnt offerings and for thank offerings and for freewill offerings and for burnt-offerings, daily[

8 ]and for the doors and for all the work of the house the[y] (or: he) will br[ing

9 the [fe]stival of fresh oil. They will bring wood two [by two

10 ]the ones who bring on the fir[st] day, Levi[

11 Reu]ben and Simeon and [on t]he fou[rth] day[

The first four lines of this fragment are taken from Lev 23:42$24: 2$, quoting the last two verses of the instructions for the Sukkot festival, as well as a summarizing verse (44), and the beginning of chapter 24 . However, the beginning of chapter 24 has been truncated, now serving as the introduction to additional laws concerning offerings. These laws are not found in the Pentateuch; however, portions of this extrabiblical material in $4 \mathrm{QRP}$ are based on material found elsewhere in the Bible or in Qumran literature. Among other things, the text mentions a festival not known from the Bible but found in $11 \mathrm{QT}^{\mathrm{a}}$ and one of the calendar texts, ${ }^{9}$ the festival of fresh oil (1. 9). Lines 10 and 11 probably refer to the Wood Festival, also known from $11 \mathrm{QT}^{\mathrm{a}}$.

The placement of the nonbiblical material here after the festival calendar gives the Mosaic imprimatur to festivals celebrated by at least some groups of Jews in the postexilic period. Notice that there is no scribal indication that this is nonbiblical material; the text flows out of biblical and into nonbiblical material as if there were no difference between the two.

Although Tov and I have considered this fragment as part of $4 \mathrm{Q} 365$, it differs from all the other fragments of $4 \mathrm{Q} 365$, and indeed of $4 Q R P$ as a whole, in that it introduces completely new material. It even differs from frag. 6 of 4Q365 where an additional song was added to the text, since that song probably expands the Song of Miriam, which is found in the biblical text; its expansion in 4Q365 would therefore suit the character of $4 \mathrm{QRP} .{ }^{10}$ The additional material in the present fragment, however, presents material not found

\footnotetext{
${ }^{9} 4 \mathrm{Q} 327,4 \mathrm{QCalendrical} \mathrm{Doc.} \mathrm{E}^{\mathrm{b}}$, col. v. I would like to thank S. Talmon for this reference.

${ }^{10}$ S. White, "4Q364 and 365: A Preliminary Report," The Madrid Qumran Congress.
} 
among the biblical laws. Thus, Yadin, emphasizing this fragment's similarities in content with $11 \mathrm{QT}^{\mathrm{a}}$, published this fragment as part of an additional copy of the Temple Scroll. ${ }^{11}$ The following arguments may be used to identify frag. 23 as part of a copy of the Temple Scroll: (1) The festival of fresh oil (1.9) is known from $1_{11 T^{a}}$ (col. xxii). However, since the fresh oil festival is not unique to the Temple Scroll and this fragment, but is also found in a fragment of a different document (the calendar text $4 \mathrm{Q} 327$, to be published by $\mathrm{S}$. Talmon), the mere mention of the fresh oil festival does not mean that frag. 23 belongs in the Temple Scroll. (2) After the festival of fresh oil, frag. 23 apparently goes on to discuss the wood festival (את העצים יקריבו, 1. 9), the appointed time of the offering of wood for the sacrifices in the temple. Such a wood offering first appears in the Bible at Neh 10:35 and 13:31, where the text mentions the offering of wood on fixed dates by certain prominent families. The closest parallel to frag. 23, however, occurs in $11 \mathrm{QT}^{\mathrm{a}}$, cols. xxiii and xxiv, which contain material concerning the wood festival. If lines 10-11 are indeed discussing the wood festival, the two festivals (oil and wood) are juxtaposed in this fragment in this sequence as they are in $11 \mathrm{QT}^{\mathrm{a}}$. In addition, in lines 10-11, the order of the tribes bringing an offering of wood (apparently on consecutive days) as far as it is extant on the fragment (day 1: Levi; day 3: Reuben and Simeon) is identical with the order of the tribal offerings for the wood festival in $11 \mathrm{QT}^{\mathrm{a}}$ (day 1: Levi and Judah; day 2: Benjamin and Ephraim and Manasseh; day 3: Reuben and Simeon; day 4: Issachar and Zebulon; day 5: Gad and Asher). This order, which is apparently also found in a fragment of $11 \mathrm{QT}^{\mathrm{b}}$ published by Yadin, PAM 42.178 (Yadin, 38*:1; see below), does not appear elsewhere in ancient Jewish literature. (3) The evidence of PAM 42.178 should also be considered in this context. The content of the fragment is as follows:

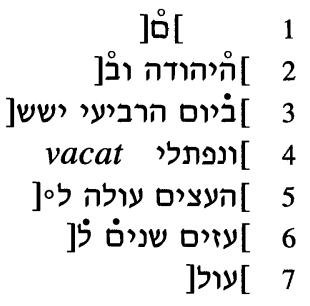

${ }^{11}$ Yadin, vol. 3, supplementary plates, pl. 40*, 1. 
This fragment overlaps with frag. 23 and with $11 \mathrm{QT}$, col. xxiii, at:

3 בוּום הרביעי (frag. 23, line 11)

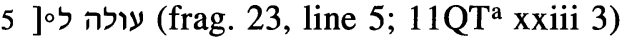

6 עזים שניל לים (frag. 23, line 9; 11QT xxiii 4)

Since PAM 42.178 is part of $11 \mathrm{QT}^{\mathrm{b}}$, its tie with frag. 23 may be an argument for frag. 23's inclusion in the Temple Scroll. However, the overlaps of PAM 42.178 with frag. 23 do not demonstrate that they are the same text, since the overlapping phrases occur in a different order on PAM 42.178 than they do on frag. 23. It may be that PAM 42.178 is giving, in lines $1-4$, the order of the tribal offerings for the festival of fresh oil, followed by the beginning of the section on the wood festival (lines 5-7). This is not the text of either frag. 23 or $11 \mathrm{QT}^{\mathrm{a}}$, and may point to a different recension of the Temple Scroll in $11 \mathrm{QT}^{\mathrm{b}}$. Therefore, it cannot be used as evidence for including frag. 23 in the Temple Scroll as presented in 11QT ${ }^{\mathrm{a}}$.

The arguments against viewing this fragment as part of another copy of the Temple Scroll are as follows: (1) The fragment begins with a direct quotation of Lev 23:42ff., in which God is speaking to Moses. Since the name Moses never occurs in 11QT ${ }^{\mathrm{a}}$, frag. 23's mention of Moses does not accord with the literary practice of the Temple Scroll. ${ }^{12}(2)$ The material of frag. 23 , lines 5-12 is similar in content to certain columns of $11 \mathrm{QT}^{\mathrm{a}}$, as noted above, but there are no textual overlaps. In fact, the material in $11 \mathrm{QT}^{\mathrm{a}}$ concerning the offering of the wood festival (cols. xxiii-xxiv) is much longer and does not fit into the available lacunae in the lines of frag. 23. Wacholder places the contents of lines 9-12 of frag. 23 in $11 \mathrm{QT}^{\mathrm{a}}$ xxiii 03-2, using, as suggested by Yadin, lines 2-5 of PAM 42.178 $\left(11 \mathrm{QT}^{\mathrm{b}}\right.$ ) to supplement col. xxiii of $11 \mathrm{QT}^{\mathrm{a}}$ (see above), creating a reconstruction of $11 \mathrm{QT}^{\mathrm{a}}$ xxiii $03-2$. However, by restoring $11 \mathrm{QT}^{\mathrm{a}}$, col. xxiii as he does, Wacholder is forced to separate the content of lines 9-12 from the rest of the contents of frag. 23, because the complete contents of frag. 23 cannot be placed in $11 \mathrm{QT}{ }^{\mathrm{a}} \cdot{ }^{13}$ At best,

12 B. Levine first noted the usage וידבר יהוה אל מושה as different from that of 11QT' ("The Temple Scroll: Aspects of its Historical Provenance and Literary Character," BASOR 232 [1978]: 5-23).

${ }^{13}$ While the contents of frag. $23,11.9-12$ and $11 \mathrm{QT}^{\mathrm{a}}$, col. xxiii, are certainly similar, it is not correct to separate the beginning of the fragment (1l. 1-4, Lev 23:42$24: 2$, and 11. 5-8, non-biblical material) from 11. 9-12 in order to locate the contents of 11. 9-12 within the Temple Scroll. Furthermore, the textual overlap that Wacholder 
frag. 23 reflects a text which in some details runs parallel to $11 \mathrm{QT}^{\mathrm{a}}$, but was much shorter. It is possible that frag. 23 may at this point be quoting (an unknown portion of) the Temple Scroll, either $11 \mathrm{QT}^{\mathrm{a}}$ or $11 \mathrm{QT}^{\mathrm{b}}$, but it would be equally possible that $11 \mathrm{QT}^{\mathrm{a}}$ was using the text of frag. 23 and expanding it. ${ }^{14}(3)$ The crease found on the fragment, which resembles the crease on frag. 12b of $4 \mathrm{Q} 365,{ }^{15}$ is another argument, this time from physical evidence, in favor of frag. 23's inclusion in 4Q365. For all these reasons, which seem more compelling than the arguments for frag. 23's inclusion in the Temple Scroll, frag. 23 has been kept in 4Q365.

Let us now turn to frag. 2*, which Yadin also published as a part of another copy of the Temple Scroll, but Strugnell placed with $4 Q R P$.

Col. i

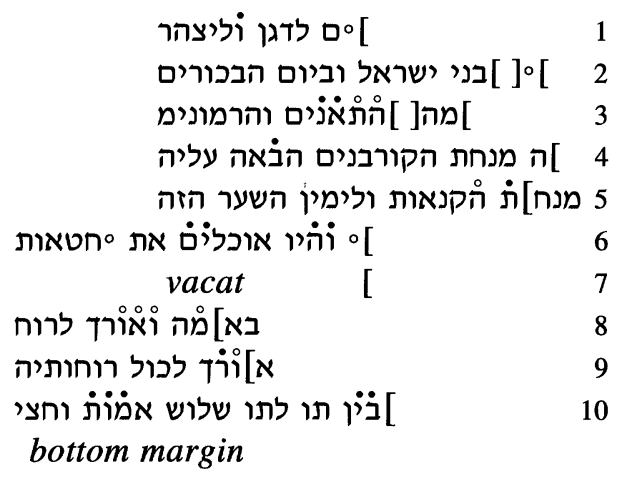

Translation:

1 ]? for grain and for oil

2 ]the children of Israel; and on the day of first-fruits

3 ]the figs and the pomegranates

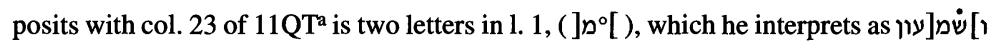
from 1.11 of frag. 23. There is no other evidence for placing 11. 9-12 of frag. 23 in the upper part of col. xxiii of $11 \mathrm{QT}^{\mathrm{a}}$. Although there are more textual overlaps with PAM 42.178, these overlaps occur in a different order and cannot be used in Wacholder's reconstruction without ignoring the physical evidence of either frag. 23 or PAM 42.178.

${ }^{14}$ Wise, in fact, suggests (p. 50) that this fragment is part of a "proto-Temple Scroll," one of the sources of $11 \mathrm{QT}^{\mathrm{a}}$.

${ }^{15}$ See the discussion in DJD 13, forthcoming. 
4 ]an offering of the sacrifices which comes along with it

5 the offer]ing of jealousies; and to the right of this gate

6 ]and they will be eating the sin offerings

7 vacat

8 by cu]bit and (the) length, to the direction of

9 lo]ng for all its directions

10 ]between chamber and chamber three and a half cubits

This first column runs parallel with col. $\mathrm{xxxviii}$ of $11 \mathrm{QT}^{\mathrm{a}}$, at the end of the description of the inner court of the temple and the beginning of the description of the construction of the middle court. There are overlaps between this fragment and col. xxxviii of $11 \mathrm{QT}^{\mathrm{a}}$ in the following places:

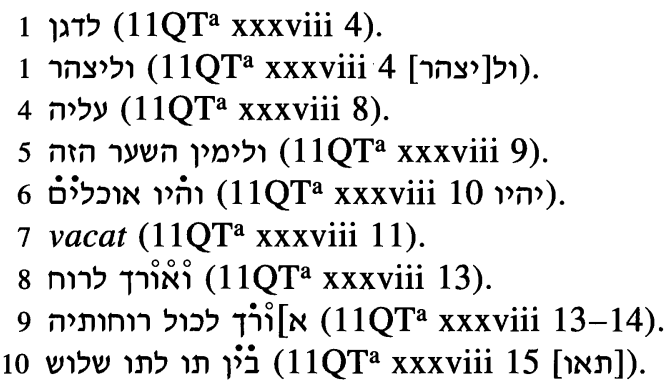

As may be seen, lines 1-6 of col. i contain several overlaps with $11 \mathrm{QT}^{\mathrm{a}} \mathrm{xxxviii} 4-10$, but the remains of either document are too fragmentary to place together without extensive reconstruction. However, it is clear that the material is closely related. The contents of these lines refer to the locations (in the inner court of the temple?) where the priests ate the sacrifices and the firstfruits, which is also the subject of $11 \mathrm{QT}^{\mathrm{a}} \mathrm{xxx}$ viii $1-10$. It is significant that both texts contain an empty space for paragraph marking here at the end of this material and before the beginning of the next subject. This shows that, whether or not they were copies of the same or different documents, they were ordering their material in the same way.

The main overlap between frag. $2^{*}$, col. i and $11 \mathrm{QT}^{\mathrm{a}}$, col. xxxviii, occurs in the material discussing the construction of the middle court. These overlaps are substantial enough to assume a common text, parallel in nature, but not identical. The contents of $11 \mathrm{QT}^{\mathrm{a}}$, lines $12-15$, are as follows:

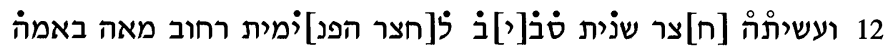

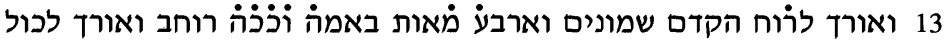




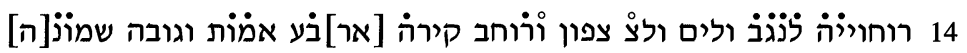

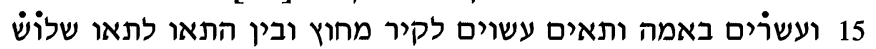

Because of the fragmentary nature of both documents, their exact relation cannot be determined. However, it is clear that all of the material found in $11 \mathrm{QT}^{\mathrm{a}}$ cannot be fitted into the lines of frag. $2 * \mathrm{i}$ (note that in the reconstruction of this column in his commentary, Yadin must posit an extra line between lines 9 and 10 in order to include all the material from $11 \mathrm{QT}^{\mathrm{a}}$ ). Frag. $2^{*} \mathrm{i}$ may have been shorter than $11 \mathrm{QT}^{\mathrm{a}}$, or from a similar, but not identical, composition. My reconstruction of frag. $2 *$ i $8-10$, including the contents of $11 \mathrm{QT}^{\mathrm{a}} \mathrm{xxxviii} 12-15$, which graphically demonstrates the difficulty of positing identical texts, is given below (p. 272).

The reconstruction makes clear that frag. $2 *$ i could not have had an identical text to $11 \mathrm{QT}^{\mathrm{a}} \mathrm{xxxviii} 12-15$. The contents of line 10 are too great to fit into one line of text. Frag. $2 *$ must have had a shorter text than $11 \mathrm{QT}^{\mathrm{a}}$, although the exact nature of the shortening is unknown. ${ }^{16}$

Column ii contains the closest parallel to $11 \mathrm{QT}^{\mathrm{a}}$ :

Col. ii

1 מאות באמה ומשער זבולון עד שער גד ששיْםْ] ושלוש מאות באמה

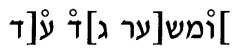

2

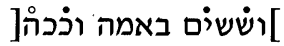

3

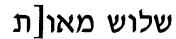

4 ומשער אשר עד פנת מזרח\}רִּ שלוש מאות וששים באמה

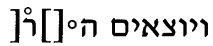

באים

5

פתחי השעריำ

\footnotetext{
16 Wacholder ("Fragmentary Remains," p. 33) transcribes the contents of col. i into his reconstruction of col. xxxviii of $11 \mathrm{QT}^{\mathrm{a}}$. He does not attempt to reconstruct the column structure of this fragment. If Wacholder's reconstruction, based on 11QT ${ }^{\mathrm{a}}$ and his own restoration of the missing material, is used for col. $i$, the letter space count for complete lines is as follows: 1. 3, 55;1.4, 65;1. 5, 57;1. 8, 56;1. 9, 56;1. 10, 110. As can be seen, 1.4 is longer than the other lines, and the problem of the substantially longer length of 1.10 also remains unresolved (Wacholder does not discuss the difficulty). Since the remains of $11 \mathrm{QT}^{\mathrm{a}} \mathrm{xxxviii}$ 4-11 are so scanty, Wacholder's reading of these lines, with the inclusion of the contents of frag. $2 * i$, depends on the acceptance of his reconstruction
} 
6 באמה וגובהמה שُמונה ועשרים באמה עד \}רִמשקוֹפִ ומן המשקופ ומקירים שמחים

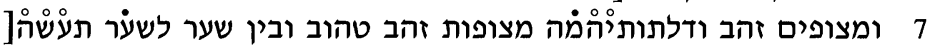

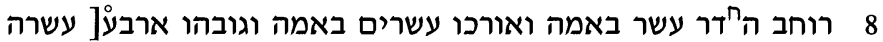

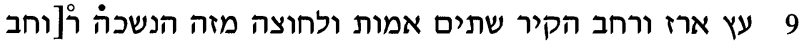

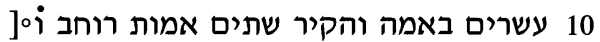
11 עצי ארז ופתחה שלוש אמות רוחב הْת שמת bottom margin

Translation:

1 ]hundred cubits, and from the gate of Zebulon to the gate of $\mathrm{Gad}$, sixty [and three hundred cubits], and from the gate of [G]ad t[o

2 and sixty cubits, and from this corner to the gate of Dan, th[ree hundred] and sixty cubits, and likewise[

3 the gate of Naphtali, sixty and three hundred cubits, and from the gate of Naphtali to the gate of Asher, three hundr[ed and sixty] cubits,

4 and from the gate of Asher to the eastern corner, three hundred and sixty cubits, and coming forth[

5 seven cubits, and in front of them protruding inside the wall of the enclosure six and thirty cubits, and the breadth of the openings of the gate[s

6 cubits, and their height twenty-eight cubits to the lintel, and being roofed[

7 and gilded with gold, and their doors, gilded with pure gold; and between gate and gate you will make[

8 the breadth of the chamber ten cubits, and its length twenty cubits, and its height four[teen cubits

9 cedar wood and the breadth of the wall two cubits, and outside the room the br[eadth

10 twenty cubits and the wall, its width two cubits[

11 cedar trees and its opening three cubits in width. The[

This column runs parallel with $11 \mathrm{QT}^{\mathrm{a}}$ xli 4 -xlii 3 , where the contents are almost identical with frag. $2 *$ ii, with the exception of line עצי ארז 11 , which is absent in 11QT ${ }^{\mathrm{a}}$. The column describes the construction of the outer court of the temple. According to $11 \mathrm{QT}^{\mathrm{a}}$, the wall of the outer court had twelve gates, named for each of the sons

of the missing text. While Wacholder's reconstruction is plausible, the difficulty with the length of 1.10 (and, to a lesser extent, 1.4) returns us to our original conclusion, that frag. $2^{*} \mathrm{i}$ had a similar, but not identical text to $11 \mathrm{QT}^{\mathrm{a}}$, col. $\mathrm{xxxviii}$. 
of Jacob (rather than the twelve tribes of Israel). This fragment preserves the names of the gates on two sides: on the west, [Issachar], Zebulon, and Gad, and on the north, Dan, Naphtali, and Asher. This order, preserved in full in $11 \mathrm{QT}^{\mathrm{a}}$, col. 41 , differs from both Num $2: 3 \mathrm{ff}$. (the encampment of the tribes around the tent of meeting) and Ezek 48:31ff. (the exits of the city of Jerusalem), and also differs from the order of the tribes prescribed for the wood festival (cf. frag. 23 above and 11QTaxxiii). It matches no other known tribal order. Thus far the two columns appear to be identical. However, there is a marked difference from $11 \mathrm{QT}^{\mathrm{a}}$ regarding the segment of frag. ${ }^{*}$ ii which has not been preserved. The two columns of the fragment, for which a bottom margin is preserved, run parallel with 11QT ${ }^{\mathrm{a}}$, cols. xxxviii and xli respectively, and it is very difficult to assume a length for frag. $2 *$ ii which would include the parallel material of $11 \mathrm{QT}^{\mathrm{a}}$. The column would contain 43 lines, assuming an average letter space count of 76, which is in itself very long for a Qumran manuscript. In addition, col. $i$ of this fragment contained a letter space count of approximately 56 (excluding line 10). This kind of variation in letter space count from column to column of the same fragment is also unusual, and leads to the conclusion that the restoration of the columns according to $11 \mathrm{QT}^{\mathrm{a}}$ cannot be accurate. As a result this fragment cannot be taken as simply a third copy of the Temple Scroll. While its verbal agreements with $11 \mathrm{QT} \mathrm{T}^{\mathrm{a}}$ are recognized in frag. $2 *$ ii, as well as in i $8-10,11 \mathrm{QT}^{\mathrm{a}}$ is much longer. The differences are thus not textual, but could be redactional. That is, $11 \mathrm{QT}^{\mathrm{a}}$ may reflect a longer recension of the Temple Scroll, and $4 \mathrm{Q} 365 \mathrm{a}$, frag. $2^{*}$ a shorter one. It is also possible that $11 \mathrm{QT}^{\mathrm{a}}$ is using frag. $2^{*}$ as a source. ${ }^{17}$

Finally, frag. 3*, which Yadin also published as part of another copy of $11 \mathrm{QT}^{\mathrm{a}}$ :

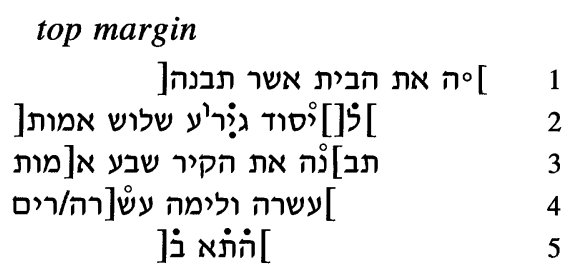

${ }^{17}$ Wise reaches this conclusion, stating that frag. $2^{*}$ is not part of the Temple Scroll, but part of a source for the Temple Scroll, which he names the "D Source." 
Translation:

1 ]the house which you will build[

2 ]the foundation recessed three cubits[

3 you will] build the wall seven cu[bits

$4 \ldots$ ?]teen, and to the west te[n (or: twen[ty)

5 ]the chamber in[...

J. Strugnell, in his preliminary notes to $4 \mathrm{Q} 365$, placed frag. $3 *$, because of its content, after frag. $2 * i$, after the beginning of the temple material, specifically above the top of frag. $2^{*}$, ii. ${ }^{18}$ However, the fragment has a sewn right margin, which precludes it from belonging to the top of the left-hand column of frag. $2^{*}$. Also, although it does include building specifications for certain structures which seem to be part of the temple compound (the house, the wall, the chamber), there is no reason to connect them with either the inner or the outer court of the temple, the subjects of frag. 2*. Therefore, Strugnell's placement does not appear sound. Yadin did not attempt to locate this fragment when reconstructing his edition of $11 \mathrm{QT}^{\mathrm{a}}$; he merely published the photograph. Wise argues that the text of frag. $3^{*}$ will not fit spatially or contextually into $11 Q T^{\mathrm{a}} \cdot{ }^{19}$ Wacholder, on the other hand, places the contents of this fragment (but not the fragment itself) into $11 \mathrm{QT}^{\mathrm{a}}$ iv $1-4$, which is the beginning of the instruction for the building of the temple. He does this because in line 1 of frag. 3* the word הבית occurs, but he offers no other evidence for his reconstruction. ${ }^{20}$ It should be noted that none of the fragments presented here will fit into the column structure of $11 \mathrm{QT}^{\mathrm{a}}$ even though they do present similar (and in the case of frag. $2 *$ identical) material. Therefore, it seems hasty to suppose that frag. $3^{*}$ must belong to the Temple Scroll because it talks about temple buildings (it is certain that it does not belong to $4 Q R P)$. The most that can be said is that its content is similar to certain passages of the Temple Scroll, and that the two texts may be related.

\footnotetext{
${ }^{18}$ If that were the case, then the proposed reconstruction of the top of the column with material from $11^{\mathrm{Q} T}{ }^{\mathrm{a}}$ would be untenable.

${ }^{19}$ He suggests, based on calculations derived from his own conjectural readings, that the structure being described here has dimensions "identical with those of the houses in the Aramaic New Jerusalem text" (p. 53).

${ }^{20}$ Wacholder, "Fragmentary Remains," pp. 7-8.
} 
In conclusion, having presented all the evidence from these fragments, the question remains whether these three fragments can be definitely identified. I am satisfied that frag. 23, because of its biblical content, is better placed with $4 \mathrm{QRP}$ than with the Temple Scroll. It may be quoting the Temple Scroll in its additional material, or the Temple Scroll may be quoting and expanding it, but a decision one way or the other is not possible without more evidence. Frag. $2^{*}$ may well belong to a different recension of the Temple Scroll than the copies we have received from Cave 11, but the material remains are too small to make a final judgment. If frag. $2 *$ is a piece of a second (or third) recension of the Temple Scroll, or part of a document like the Temple Scroll, then frag. 3* (as well as the other fragments of $4 \mathrm{Q} 365^{\mathrm{a}}$ ) probably belongs to it as well. However, since the fragments are quite small it is difficult to make a definitive statement. ${ }^{21}$ As with many of the smaller fragments of the Dead Sea Scrolls, the true nature of the textual history of these fragments remains elusive, but their content concerning festivals and temple building mark them as evidence of the intense interest of the Qumran sect in these halakhic subjects.

\footnotetext{
${ }^{21}$ For example, if one of these fragments contained a biblical quotation, then the argument about its textual nature would change, and it would be much more likely that it belonged to $4 \mathrm{QRP}$.
} 


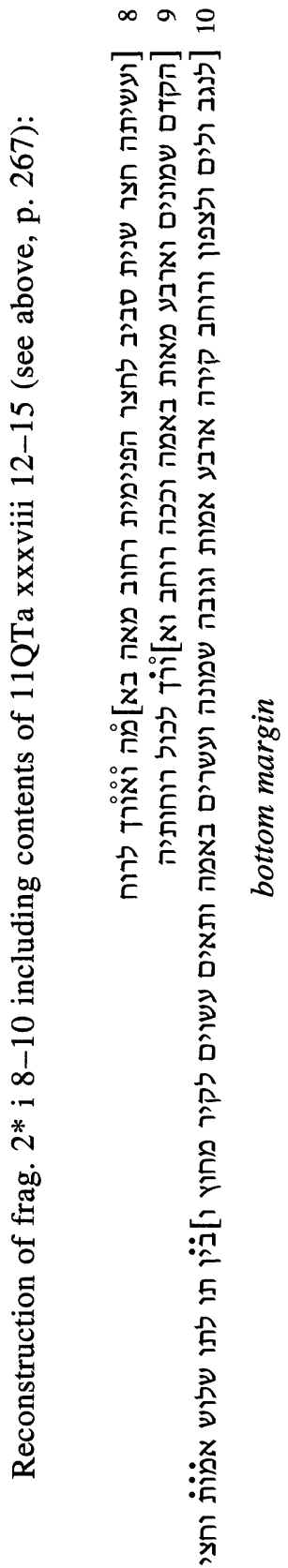



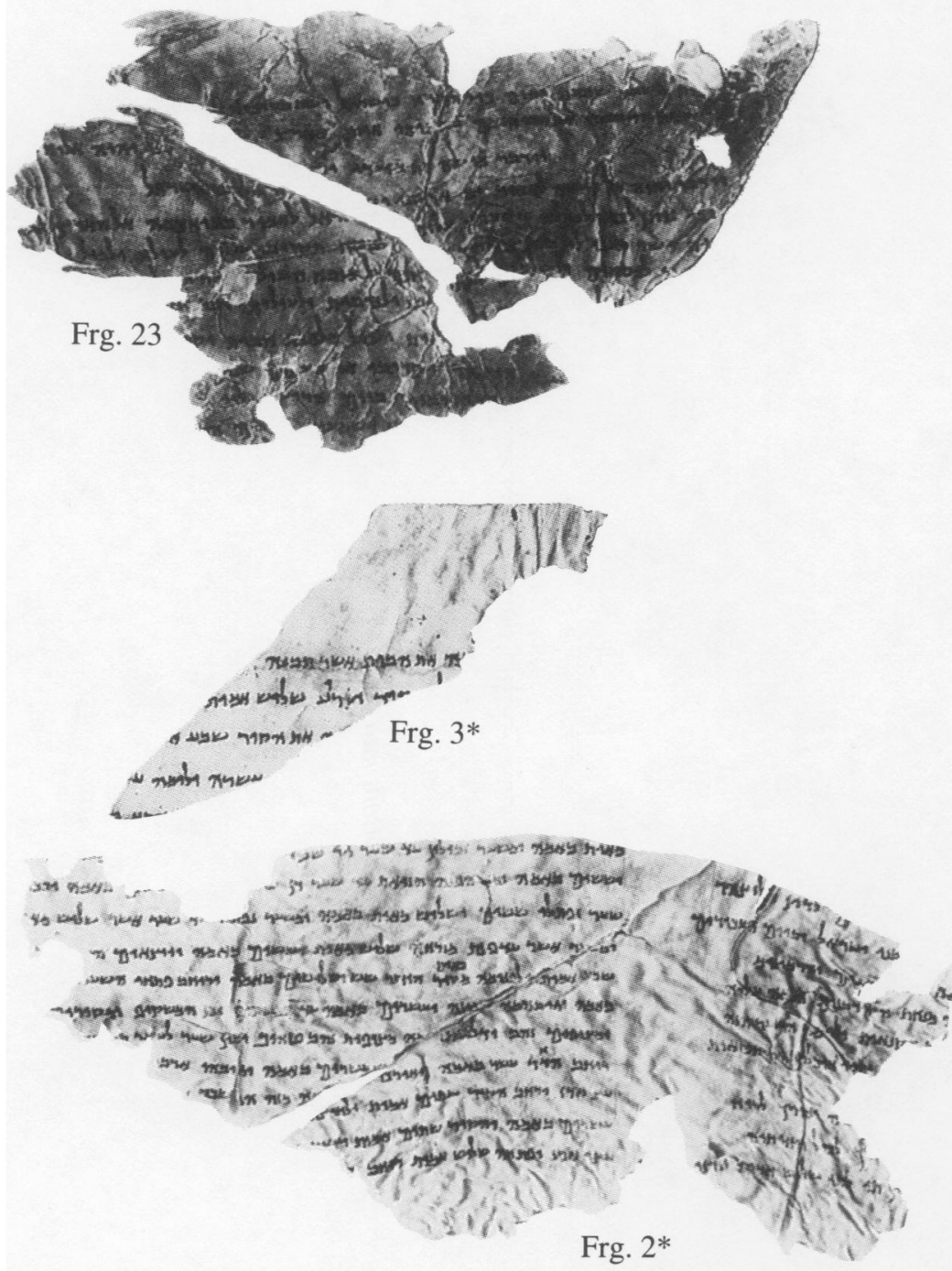

PAM 43.366

Courtesy, Israel Antiquities Authority

4Q 365 (Frgs 23)

4Q 365a (Frgs 2*, 3*) 